\title{
Post Partum Estrus of Brahman Cross Cows Inseminated with Limousine Straw in Smallholder Farm
}

\author{
Rahmat Anwar ${ }^{1}$, Sigit Bintara ${ }^{2}$, I Gede Suparta Budisatria ${ }^{3}$, Diah Tri Widayati ${ }^{2}$, and \\ Endang Baliarti ${ }^{3, *}$ \\ ${ }^{1}$ Post Graduate Student of Faculty of Animal Science, Universitas Gadjah Mada \\ ${ }^{2}$ Department of Animal Breeding and Reproduction, Faculty of Animal Science, Universitas Gadjah Jl. Fauna No. 3 , \\ Bulaksumur, Yogyakarta 55281 - Indonesia \\ ${ }^{3}$ Department of Animal Production, Faculty of Animal Science, Universitas Gadjah Mada Jl. Fauna No. 3, \\ Bulaksumur, Yogyakarta 55281 - Indonesia \\ *Corresponding author.Email: bali_artir@ugm.ac.id
}

\begin{abstract}
This study aimed to examine the postpartum estrous of Brahman Cross (BX) cows inseminated with a Limousine straw on smallholder farms. Ten BX cows were about five years old with a bodyweight between $365-430 \mathrm{~kg}$ in the last month of pregnancy was used in this study. Observations started from nine months of pregnancy until the first estrous after partus. The parameters observed included bodyweight at calving, bodywight every month during lactation to the first estrous, and duration between calving to the first estrous. The results showed the body weight at the last month of pregnancy was $410 \pm 0.23 \mathrm{~kg} / \mathrm{head}$, the bodyweight immediately after calving was $384 \pm 0.22 \mathrm{~kg}$, the bodyweight at the first month of lactation period was $369 \pm 0.22 \mathrm{~kg}$, the second month was $361 \pm 0.22 \mathrm{~kg}$, and the body weight at the postpartum estrous was $354 \pm 0.22 \mathrm{~kg}$. The daily bodyweight changes after calving were $-0.56 \pm$ $0.10 \mathrm{~kg} /$ day, $-0.23 \pm 0.34 \mathrm{~kg} /$ day and $-0.24 \pm 0.22 \mathrm{~kg} /$ day, respectively. Postpartum estrous occurred $120 \pm 1.4$ days after calving. This research concluded that postpartum estrous Brahman Cross on smallholder farmer's level was relatively good and produced calf with a good body weight.
\end{abstract}

Keywords: Postpartum Estrous, Brahman Cross, Community Livestock, Intensive Management System.

\section{INTRODUCTION}

The Indonesian government has launched a beef self-sufficiency program intending to meet domestic beef needs independently by rolling out the 2014 Beef and Buffalo Self-Sufficiency Program (PSDSK 2014). This beef cattle development program includes five main activities, which to some degree will intersect with the reconciliation of import policies and revitalization of domestic cattle marketing. The five main activities are: (a) provision of local feeder/beef; (b) increasing productivity and reproducibility of local cattle; (c) prevention of slaughter of productive female cattle; (d) provision of local cattle breeds; and (e) regulation of domestic beef stock which also includes feeder cattle stock, distribution, and marketing of beef and meat [1].
To increase the beef cattle population in Indonesia, the Government of Indonesia imports cows from Australia, including the Brahman crossbreed (BX). This breed of cattle was chosen to suit the tropical climate conditions in Indonesia because it contains the blood of Bos Indicus, which is formed from Brahman cattle and Bos Taurus cattle. Brahman cattle were formed from Ongole cattle, Khrishna Valley, Gizard from Indicus boss, crossed with Hereford, Shorthorn belonging to Boss Taurus. BX cattle can adapt to the tropics, are resistant to poor-quality feed, and have Bos taurus blood which have a larger body frame. Thus, it is expected that the BX cows will not interfere with their reproductive performance and have larger calves than local Indonesian cattle. 
In Indonesia, the management of BX cows is partly handed over to farmers, with a maintenance system as generally done by farmers; cows are kept in cages with their necks tied to poles or floors, and the feed provided does not take into account the physiological conditions needs. As cattle farming is not the primary job, attention to cattle farming management is not fully given [2]. With such maintenance characteristics, the performance, particularly reproduction, can not be optimized [3,4]. One of the reproductive performances of a cow is postpartum estrus. The short length of PPE affects reproductive efficiency [5].

PPE is influenced by a variety of variables. In addition to the feed ratio factor, the condition of the cow's body after calving is very influential. If the body condition of the cow after calving decreases, the PPE is extended [5]. The nutrition needs of the cow after calving increase in order to meet the maintenance needs, besides fulfilling the milk production to assure the calf can grow optimally. If the nutrients during lactation are insufficient, the cow's body energy reserve will be depleted, causing a decrease in body condition score (BCS) and body weight. Excessive weight loss will affect the production and activity of primary reproductive hormones, which causes disruption of follicle development in the ovary and directly affects post-partum estrus [6].

\section{MATERIALS AND METHODS}

\subsection{Materials}

Ten BX cows, about 5 years old with a bodyweight between $365-430 \mathrm{~kg}$ in the last month of pregnancy was used in this study.

\subsection{Methods}

Each cow was placed in a cage tied with a rope individually, each equipped with a feed and drink container. The feed was given in the form of $12 \mathrm{~kg}$ of fermented corn cobs, $8 \mathrm{~kg}$ of corn straw, and $15 \mathrm{~kg}$ of king grass (as fed).

The weight, height, body length, chest circumference were measured at the beginning of the experiment. The calf's birth weight and body size were recorded immediately after born. Weighing and body measurements were carried out once a month. Cow and calf were weighed when the calves were three months old, and the cows were observed until they showed signs of estrus after weaning at 90 days. During the study, feed consumption was recorded.

\section{RESULTS AND DISCUSSION}

\subsection{Cow Feed Consumption}

Feed consumption of the BX cows can be seen in Table 1.

Table 1. Average feed consumption of the cows

\begin{tabular}{|l|c|c|c|}
\hline & \multicolumn{1}{|c|}{$\begin{array}{c}\text { First } \\
\text { month }\end{array}$} & $\begin{array}{c}\text { Second } \\
\text { month }\end{array}$ & $\begin{array}{c}\text { Third } \\
\text { month }\end{array}$ \\
\hline $\begin{array}{l}\text { Fermentatio } \\
\mathrm{n} \text { of corn } \\
\text { cobs }(\mathrm{kg})\end{array}$ & $11.79 \pm 0.27$ & $11.76 \pm 0.24$ & $11.78 \pm 0.26$ \\
\hline $\begin{array}{l}\text { Dry corn } \\
\text { stalks }(\mathrm{kg})\end{array}$ & $7.17 \pm 0.22$ & $7.19 \pm 0.21$ & $7.17 \pm 0.20$ \\
\hline $\begin{array}{l}\text { King grass } \\
(\mathrm{kg})\end{array}$ & $14.72 \pm 0.43$ & $14.71 \pm 0.36$ & $14.73 \pm 0.27$ \\
\hline
\end{tabular}

The feed was given in the form of $12 \mathrm{~kg}$ of fermented corn cobs, $8 \mathrm{~kg}$ of corn straw, and $15 \mathrm{~kg}$ of king grass. The results (Table 1) showed that the average consumption of cows after calving to wean (90 days) was not significantly different from the first until the third month of lactation .

\subsection{The BX Cow's Body Weight}

Data on body weight and size of BX cows inseminated with Limousin straw on smallholder farms can be seen in Table 2 .

\subsection{Daily Body Weight Changes}

During the lactation period in this study, the cow and the calf were kept in the same cage, which allowed unrestricted access to milk suckling by the calf, leading to a significant decrease in the cow's body weight to fulfill the milk production needs evidenced by decreasing bodyweight of the cow from post-partum onwards recorded in this study.

Table 2. Changes in body weight and size of BX cows during pregnancy, shortly after giving birth, and shortly after weaning.

\begin{tabular}{|l|c|c|c|}
\hline \multirow{2}{*}{\multicolumn{1}{|c|}{ Parameter }} & \multicolumn{3}{|c|}{ BX cows physiology status } \\
\cline { 2 - 4 } & During pregnancy & Immediately after calving & Immediately after weaning \\
\hline Body weight $(\mathrm{kg})$ & $410.47 \pm 23.11$ & $384.79 \pm 22.64$ & $354.60 \pm 22.93$ \\
\hline Height $(\mathrm{cm})$ & $128.70 \pm 5.67$ & $128.70 \pm 5.67$ & $128.70 \pm 5.67$ \\
\hline Body Length $(\mathrm{cm})$ & $163.40 \pm 30.54$ & $163.40 \pm 30.54$ & $163.40 \pm 30.54$ \\
\hline Bust $(\mathrm{cm})$ & $170.50 \pm 3.24$ & $167.50 \pm 3.24$ & $165.10 \pm 6.90$ \\
\hline
\end{tabular}


According to Affandhy et al. [7] the critical point for the reproduction of cows is during pregnancy and the beginning of lactation. Feed intake that enters the cow's body is used to meet three main needs, including milk production, recovery of post-calving conditions and meeting basic living needs. Addition by Montiel and Ahuja [8], undernutrition is the main factor that inhibits livestock production, especially in the tropics and causes long estrus after calving. Changes in nutrition and the condition of the endocrine status of the parent after giving birth can affect the level of muscle protein degradation which is characterized by a decrease in body weight in some livestock. There is a limit of $25 \%$ body weight loss without changing the main body function [6] .

Data of BX cow body weight was shown in Table 3.

Table 3. Body weight and siz BX cow

\begin{tabular}{|l|c|c|}
\hline Parameter & Body weight & changes \\
\hline $\begin{array}{l}\text { Pregnancy } \\
\text { bodyweight after } \\
\text { birth }\end{array}$ & $384.79 \pm 22.64$ & - \\
\hline First month & $371.02 \pm 22.40$ & $-0.56^{\mathrm{a}} \pm 0.10$ \\
\hline Second month & $362.60 \pm 22.93$ & $-0.45^{\mathrm{a}} \pm 0.94$ \\
\hline Third month & $354.60 \pm 22.93$ & $-0.24 \pm 0.55$ \\
\hline
\end{tabular}

Previous research by [9] reported that the calf's feeding pattern strongly influenced daily weight loss. Free-feeding calves resulted in a higher daily weight loss of the cow than the calves were sucking milk 30 minutes/day $(-0.29 \pm 0.38 \mathrm{~kg} / \mathrm{head} /$ day VS $-0.23 \pm 0.4$ $\mathrm{kg} /$ head/day). In this research, the post partum daily weigh lost of BX cow was negatively correlated with the Limousin-BX (Limbra) calf daily weight gain, with the average daily gain in the first month was $0.643 \pm 0.10$ $\mathrm{kg}$, in the second month was $0.643 \pm 0.10 \mathrm{~kg}$ and in the third month was $0.632 \pm 0.4 \mathrm{~kg}$.

\subsection{Post Partum Estrus}

Postpartum estrus (PPE) of BX cows at 90 days of calf weaning was $120.7 \pm 1.4$ days. The average postpartum estrus of the study was shorter than the results of the study of [10], which were 158.6 days, and by [11] which were $4.14 \pm 0.39$ months and $3.64 \pm 1.96$ months. Crosses between BX and Limousines resulted in large calf which affected the suckling index, so that it would have an impact on PPE after giving birth.

The main factors affecting PPE are nutritional status and weaning. However, there are several other factors that influence PPE, including breed, age, number of calf, milk production, calving season, availability of males, uterine status, distocia and livestock health $[3,4]$. Calf weaning is a factor that affects the postpartum interval. Early calf weaning will support the mother to immediately estrus and mate again due to hormonal mechanisms, namely negative feedback because milk suckling does not occur. The cessation of the milk suckling process will stimulate the hypothalamus to stimulate the anterior pituitary to secrete GNRH which will affect the secretion of FSH and LH resulting in the formation of follicles and the occurrence of estrus $[12,13]$. Research results showed that PPE of BX cows was considered in a good category.

\subsection{Calf Body Weight}

The results showed that in Limbra calf birth weight was $26.17 \pm 0.38 \mathrm{~kg}$, a change in bodyweight in the first month was $45.48 \pm 0.67 \mathrm{~kg}$, the second month was $64.79 \pm 0.96$ and the third month was $84.10 \pm 1,25 \mathrm{~kg}$. The average daily gain in the first month was $0.643 \pm 0.10 \mathrm{~kg}$, the second month was $0.643 \pm 0.10 \mathrm{~kg}$ and the third month was $0.632 \pm 0.4 \mathrm{~kg}$. Data on body weight and size of the calf on smallholder farms can be seen in Table 4 .

\subsection{Birth Weight}

High birth weight will tend to produce high weaning weight and weaning growth. The results showed that the birth weight of Limbra was $26.17 \pm 0.38 \mathrm{~kg}$, which was higher than that reported by [14], $25.20 \pm 1.91 \mathrm{~kg}$. According to BIF [15], calf birth weight has a relationship with the cow's weight which can be used as a good indicator to avoid difficulties during calving.

\subsection{Weaning Weight}

Weaning weight (90 days) of Limbra calves in this study was $84.10 \pm 1.25 \mathrm{~kg}$, higher than the results of [14] which was $81.90 \mathrm{~kg}$. Bodyweight and weaning age

Table 4. Bodyweight and body size of Limbra Calf.

\begin{tabular}{|l|c|c|c|c|c|}
\hline \multirow{2}{*}{ Measurement } & \multirow{2}{*}{ Birth } & \multirow{2}{*}{ Weaning $(90$ day) } & \multicolumn{3}{|c|}{ Changes } \\
\cline { 4 - 6 } & & & First month & Second month & Third month \\
\hline Body weight $(\mathrm{kg})$ & $26.17 \pm 0.38$ & $84.10 \pm 1.25$ & $45.48 \pm 0.67$ & $64.79 \pm 0.96$ & $84.10 \pm 1.25$ \\
\hline Height $(\mathrm{cm})$ & $75.54 \pm 0.68$ & $92.46 \pm 0.98$ & $83.84 \pm 0.68$ & $89.46 \pm 0.96$ & $92.46 \pm 0.98$ \\
\hline Body Length $(\mathrm{cm})$ & $64.24 \pm 0.68$ & $90.96 \pm 0.98$ & $71.54 \pm 0.68$ & $79.46 \pm 0.98$ & $90.96 \pm 0.98$ \\
\hline Bust $(\mathrm{cm})$ & $72.84 \pm 0.68$ & $92.56 \pm 1.27$ & $81.74 \pm 0.68$ & $90.96 \pm 0.98$ & $92.56 \pm 1.27$ \\
\hline ADG & & & $0.643 \pm 0.10$ & $0.643 \pm 0.10$ & $0.632 \pm 0.4$ \\
\hline
\end{tabular}


vary depending on the size and rate of growth of cattle $[16,17]$. In smallholder farm, the calf weaned in 205 days, as the weaning weight is defined as the weight when the cow is weighed at 205 days old. Weaning at an earlier age will have a lower percentage of weaning weight compared to calves that are weaned at 205 days because weaning at an early age causes low feed consumption so that only a small amount of nutrients is absorbed [18].

\section{CONCLUSION}

This study revealed that the cross between Brahman cross cows and Limousine straw on community livestock farmer produced big calves, which affected cow weight loss and the length of postpartum estrus, regardless of the fact that PPE was still categorized as good (120.71.4 days). This indicated a promising future for BX-Limousine crossbreeding to increase the national population.

\section{ACKNOWLEDGMENTS}

The author would like to thank the Universitas Gadjah Mada, who has supported this research financially through student Final Project Recognition 2021, and to the farmer who has given permission and provided research material.

\section{REFERENCES}

[1] Ditjen Peternakan. 2011. Blue Print Program Swasembada Daging Sapi 2014. Direktorat Jenderal Peternakan, Kementerian Pertanian. Jakarta

[2] A. E. T. Sulfiar, B. A. Atmoko, B. Guntoro, and I. G. S. Budisatria, "The Profiling of the Farmers with Semi-Intensive and Intensive Cattle Production Systems in South Konawe District, Southeast Sulawesi Province," IOP Conf. Ser. Earth Environ. Sci., vol. 465, no. 1, p. 012061, 2020, doi: 10.1088/1755-1315/465/1/012061

[3] I. G. S. Budisatria, B. Guntoro, A. E. T. Sulfiar, A. Ibrahim, and B. A. Atmoko, "Reproductive management and performances of Bali cow kept by smallholder farmers level with different production systems in South Konawe Regency, Indonesia," IOP Conf. Ser. Earth Environ. Sci., vol. 782, no. 2, p. 022079, 2021, doi: 10.1088/1755-1315/782/2/022079

[4] E. Baliarti, I. Setiawan, T.S.M. Widi, B. Suhartanto, H. Maulana, B.A. Atmoko, A. L. Astrini, "Performances of Bali cow kept by the palm oil farmers in Rokan Hulu, Riau" IOP Conf. Ser. Earth Environ. Sci., vol. 902, no. 1, p.
012053, 2021, doi: $10.1088 / 1755-$ $1315 / 902 / 1 / 012053$

[5] E. Baliarti, B. Atmoko, F. Ariyanti, N. Ngadiyono, I.G.S. Budisatria, Panjono, T.S.M Widi, and M.D.E. Yulianto, "Postpartum estrus variation of local cows at village breeding center in Yogyakarta Province Indonesia" Proceeding of The 1st International Conference on Tropical Agriculture ed nuringtyas $\mathrm{T}$ Isnansetyo $\mathrm{A}$. (Springer, Cham) pp 377-381, 2017. https://doi.org/10.1007/978-3-319-60363-6_37

[6] M. Diskin and D. Kenny, "Managing the reproductive performance of beef cows," Theriogenology, vol. 86, pp. 379-387, 2016.

[7] Affandhy L, Pamungkas D, Ratnawati D. 2008. Respons reproduksi sapi potong induk pada umur penyapihan pedet berbeda di kondisi peternakan rakyat di lahan kering. Dalam: Sani Y, Martindah E, Nurhayati , Puastuti W, Sartika T, Parede L, Anggraeni A, Natalia L, penyunting. Inovasi teknologi mendukung pengembangan agribisnis peternakan ramah lingkungan. Prosiding Seminar Nasional Teknologi Peternakan dan Veteriner. Bogor, 11-12 November 2008. Bogor (Indonesia): Puslitbangnak. hlm. 132-136.

[8] Montiel F, Ahuja C. 2005. Body condition and suckling as factors influencing the duration of postpartum anestrus in cattle: a review. Anim Reprod Sci 85:1-26.

[9] Browning Jr., R., B.S. Robert, A.W. Lewis, D.A. Neuendorff and R.D. Randel, 1994. Effects of Postpartum Nutrition and Once-Daily Suckling on Reproductive Efficiency and Preweaning Calf Performance in Fall-Calving Brahman (Bos indicus) Cows. Journal Of Animal Science. 72: 984-989.

[10] Ratnawati D, Affandhy L, Dikman DM, Indrakusuma DA. 2012. Peningkatan performa reproduksi sapi induk Brahman Cross dan turunannya pada tingkat di Jawa Timur. Laporan Akhir kerjasama ACIAR dan Loka Penelitian Sapi Potong.

[11] Riatnawati, T. 2010. Karakteristik dan Kinerja Induk Sapi Peranakan Ongole dan Sapi persilangan Simmental dengan Peranakan Ongole di Kecamatan Mlati Kabupaten Sleman. Skripsi. Fakultas Peternakan Universitas Gadjah Mada. Yogyakarta

[12] Hafez B. 2000. Reproduction in farm animals. 7th Edition. Reproductive health center. IVF 
Andrology International. South Carolina (US): Kiawah Island.

[13] B. A. Atmoko, S. Bintara, D. Maharani, A. Ibrahim, and I. G. S. Budisatria, "Estrous response of Etawah Crossbred does on estrous synchronization using the prostaglandin $\mathrm{f} 2 \alpha$ based protocol," IOP Conf. Ser. Earth Environ. Sci., vol. 465, no. 1, pp. 6-11, 2020, doi: 10.1088/1755-1315/465/1/012044.

[14] Kurniawan, F. A. 2020. Performa Sapi Hasil Silangan Brahman Cross (BX) di PT Lembu Jantan Perkasa (PT LJP) (Doctoral dissertation, Bogor Agricultural University (IPB)).

[15] BIF (Beef Improvement Federation). 2018. Guidelines for Uniform Beef Improvement Programs. 9th ed. Kansas (USA): Kansas State Univ.

[16] E. Baliarti, I. G. S. Budisatria, Panjono, B. A. Atmoko, and M. Hamdani, "Calf production of Bali cows in cattle-oil palm plantation integration system in Riau Province Indonesia," IOP Conf. Ser. Earth Environ. Sci., vol. 518, p. 012015, 2020, doi: 10.1088/1755$1315 / 518 / 1 / 012015$.

[17] N. Ngadiyono., E. Baliarti., T.S.M. Widi., H. Maulana and B.A. Atmoko. Effect of breed and initial body weight on daily weight gain of Simmental Ongole Crossbred cattle and Ongole Grad cattle. IOP Conf. Series: Earth and Environmental Science Vol 387, Yogyakarta 2019, Pp 1-4. https://doi:10.1088/17551315/387/1/012044.

[18] Kaswati, Sumadi and N. Ngadiono. 2013. Estimasi nilai heritabilitas berat lahir, berat sapih dan umur satu tahun pada sapi Bali di Balai Pembibitan Ternak Unggul Sapi Bali. Buletin Peternakan. 37(2):74-78. 